\title{
SUSTAINABLE WATER MANAGEMENT ANALYSIS OF THE SELWYN CATCHMENT USING NESTED ADAPTIVE SYSTEMS
}

\author{
B. JENKINS \\ Waterways Centre for Freshwater Management, University of Canterbury and Lincoln University, \\ Christchurch New Zealand.
}

\begin{abstract}
The paper uses the approach of "nested adaptive systems" to establish an operational definition of sustainable management for the Selwyn catchment of the South Island of New Zealand. The Selwyn River is an undammed alluvial river that is under intense pressure for groundwater abstraction and water quality effects from land use intensification in its catchment. It is also subject to large flow fluctuations. Different spatial scales were determined for sustainability analysis. Using the adaptive cycle of exploitation, accumulation, disturbance/release and reorganisation, critical variables for maintaining the resilience of the catchment in relation to land and water use pressures and the thresholds of these critical variables for management interventions to achieve sustainable systems were identified. Also crucial for sustainability was the maintenance of the linkages between the different spatial scales. For each issue, the findings from the sustainability analysis are compared with current management approaches which are primarily derived from responses to effects-based assessment of new development proposals. The sustainability analysis identifies the need for more comprehensive management approaches.

Keywords: adaptive cycle, critical variables for resilience, nested spatial scales, sustainable irrigation system vulnerability.
\end{abstract}

\section{INTRODUCTION}

\subsection{Nested adaptive system framework}

The framework of nested adaptive systems is used for sustainability analysis. This is based on the four phases of the adaptive cycle Gunderson and Holling [1]:

- Exploitation: the use of resources.

- Accumulation: the build-up of material or energy in the system.

- Disturbance/release: a disturbance to the system that can cause the release of material or energy and change the structure and function of the system.

- Reorganisation: the restructuring of the system after disturbance.

System response can be a recovery of the original system (i.e. sustainable) or a shift to an alternative state (i.e. unsustainable). The adaptive cycle can be depicted as a lissajous figure (Fig. 1).

Systems can be nested: they can operate at different spatial and time scales which are linked. This provides an operational basis for defining sustainability. Sustainability is the maintenance of the structure, function and relationships in the adaptive cycles across different time and geographical scales. A key property for sustainability is "resilience" - the capacity of a system to absorb disturbance and still retain its basic function and structure [2]. 


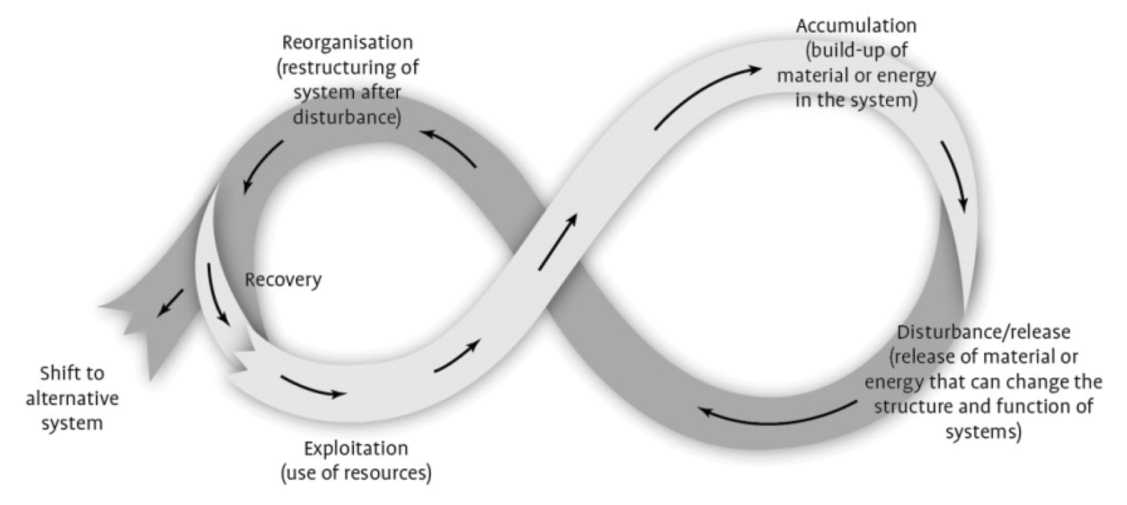

Source: Adapted from Gunderson and Holling 2002

Figure 1: The adaptive cycle.

The terminology of the adaptive cycle is derived from ecosystem theory [3]. The exploitation and accumulation phases are from ecosystem succession theory where exploitation is the colonisation by pioneering species and accumulation is the development of the climax community better adapted to average conditions. The disturbance/release and reorganisation phases are from ecosystem disturbance theory where natural or human-induced disturbance (e.g. forest fires through lightning strikes or slash-and-burn agriculture) which disrupts an ecosystem, is followed by a recovery phase. The disturbance phase is associated with the release of resources (e.g. in slash-and-burn agriculture, nutrients in the ashes of burnt vegetation are released to the soil facilitating crop growth). Recovery can be a return to the original system or a change to an alternative system (e.g. slash-and-burn agriculture confined to small areas and with adequate fallow periods can be perpetually repeated but when applied to large areas or with inadequate fallow periods desertification can occur).

The adaptive cycle concept is also characteristic of other types of systems (e.g. in economics, Schumpeter's concept of "creative destruction" where product innovation disrupts a stable market leading a new market [4]). One of the early applications to water resource systems was in managing lake water quality in agricultural catchments. Adaptive cycles and management interventions were developed to address three phosphorus failure pathways to water quality degradation with different time frames: the soil (slow turnover), lake sediments (intermediate turnover) and lake water (fast turnover) [5].

Linked adaptive cycles are identified for the Selwyn catchment sustainability issues. For sustainability analysis priority needs to be given to the critical variables that create the greatest vulnerability to an adaptive cycle and to the linkages between the different spatial and temporal scales. The critical variables for potential system failure pathways are analysed to test whether they are near or exceed resilience thresholds. Management interventions to ensure that critical variables are within resilience thresholds and that the linkages between different scales are maintained are the essence of an operational basis for sustainability. The areas warranting management intervention for each issue are identified and compared with current management approaches. A similar analysis has been undertaken for water management issues in the Waimakariri catchment [6]. 
The focus of the paper is on the high level application of the methodology to identify key issues warranting management intervention rather than a detailed technical analysis. For the analysis, the method used is the sustainability analysis framework. The source of data is from secondary sources cited in the paper. The approach highlights the key issues and their underlying processes for the catchment identified using the nested adaptive systems framework. These issues were not identified in a traditional catchment management framework [7] or adequately managed in an effects-based assessment of further irrigation development [8].

\subsection{Sustainable water management issues in the Selwyn catchment}

The paper considers the sustainability of water extraction for irrigation on water quantity and the cumulative impacts of land use intensification on water quality in the Selwyn catchment. The headwaters of the Selwyn River are in the foothills of the Southern Alps of the South Island of New Zealand. The river crosses the alluvial Central Plains of the Canterbury region and discharges into Lake Ellesmere/Te Waihora. In the upper reaches the river loses surface water to the groundwater system while in the lower reaches when the groundwater table reaches the elevation of the river bed the river gains flow from groundwater. A longitudinal section of the river is shown in Fig. 2. The middle reach is ephemeral [9]. The flow permanence along the length of the river is shown in Fig. 3.

In relation to water extraction for irrigation, water demand has increased with conversion of dryland farms to irrigation, mainly for maintaining pasture for dairying. The principal source of water is groundwater. Groundwater withdrawal lowers the groundwater table which increases the ephemeral reach of the Selwyn River and reduces the connectivity between the

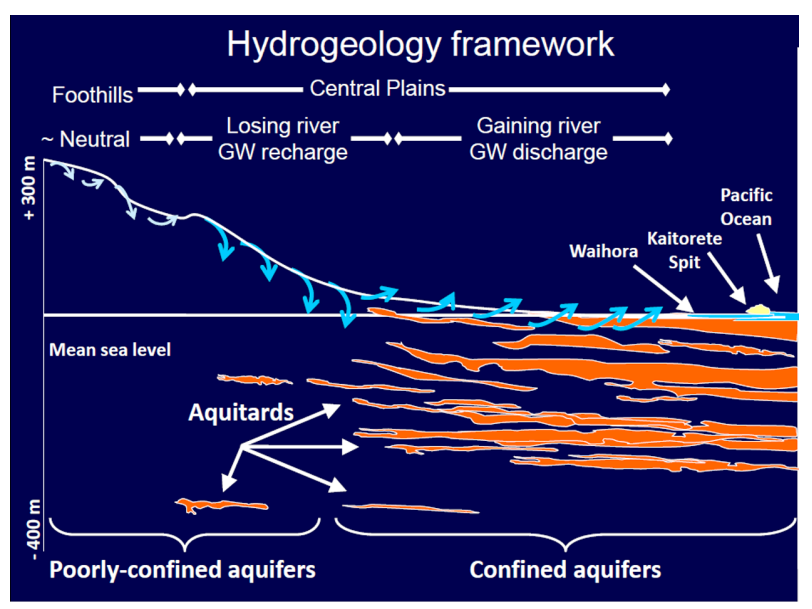

Figure 2: Longitudinal section of gaining and losing reaches of the Selwyn River [10]. The river profile is from the foothills across the Central Plains to the coastal lake (Waihora) where there is a barrier bar (Kaitorete Spit) which is artificially opened to allow discharge to the Pacific Ocean. Across the Central Plains there is initially a losing reach with recharge to groundwater (shown by the downward arrows). At lower elevations the river changes to a gaining reach with groundwater discharging into the river (shown by upward arrows). The groundwater system is unconfined in the upper reaches of the Central Plains. Bands of confining layers are present closer to the coast. 


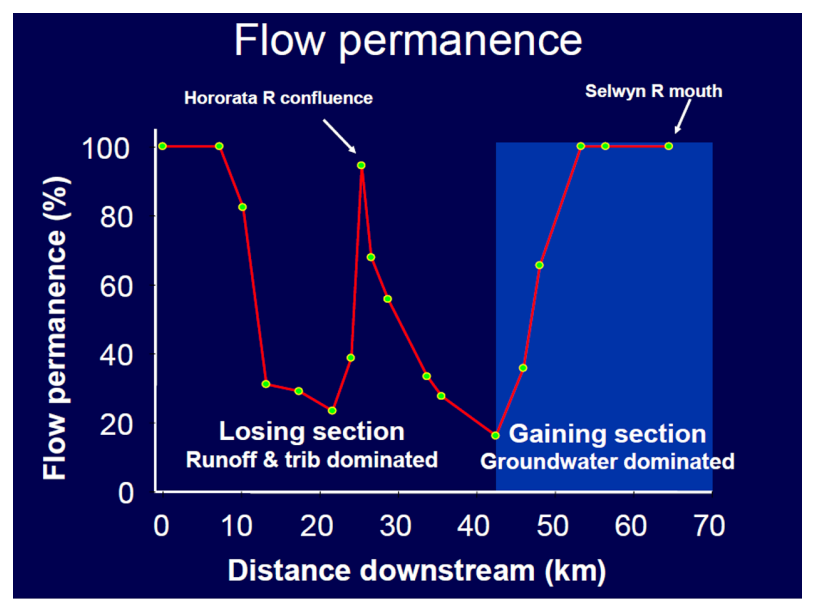

Figure 3: Flow permanence along the length of the Selwyn River [10]. The graph plots flow permanence (the $\%$ of time the river is flowing) against the distance downstream from the headwaters to the mouth of the Selwyn River at Te Waihora/Lake Ellesmere. Flow in the losing section in the upper reaches is dependent on rainfallrunoff and tributary flow. The Hororata River tributary increases flow permanence around the confluence. Flow permanence declines to around $40 \mathrm{~km}$ downstream until groundwater inflow in the gaining reach increases flow permanence in the Selwyn River.

upper and lower reaches of the river [9]. In Section 2, this process is considered as an adaptive cycle in relation to the implications of the drying reach of the Selwyn River on fish ecology. Possible management interventions are identified to facilitate sustainable management.

With respect to cumulative impacts on water quality, land use intensification in the Selwyn catchment has led to increased nutrient generation from fertiliser application, animal effluent disposal and animal urine patches. Of particular concern in the Selwyn catchment is nitrate contamination of groundwater and the lower reaches of the Selwyn River from groundwaterfed flows. In Section 3, this process is considered as an adaptive cycle in relation to the effects on water quality. Possible management interventions to achieve sustainable management are identified.

Section 4 provides a discussion and conclusions from the application of the nested adaptive systems framework to these water management issues in the Selwyn catchment.

\section{MANAGEMENT OF THE DRYING REACH OF THE SELWYN RIVER}

\subsection{Adaptive cycle for the Selwyn River flow regime}

In representing the flow regime of the Selwyn River as a nested adaptive system, it is appropriate to consider two linked adaptive cycles: one for upper losing reach and a separate one for the lower gaining reach, with the two reaches linked by both surface water and groundwater.

The key components of the adaptive cycle for the upper losing reach of the Selwyn River are (Fig. 4): 


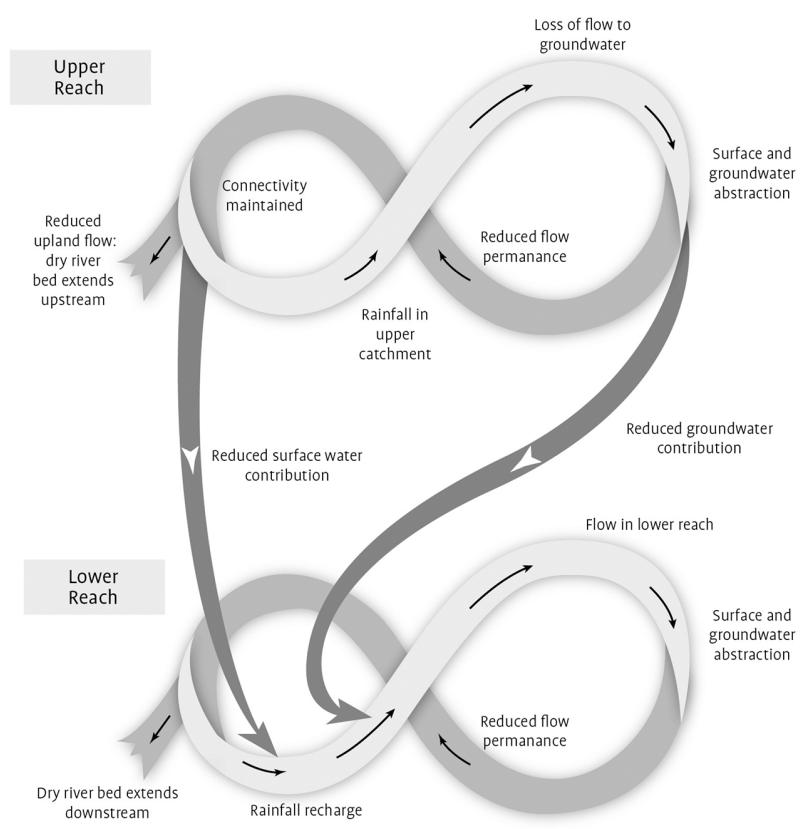

Figure 4: Linked adaptive cycles of upper and lower river reaches.

- Exploitation: rainfall runoff in the upper foothills catchment.

- Accumulation: the runoff seeping into groundwater.

- Disturbance-release: groundwater and surface water that is extracted for irrigation and the associated drying of the river bed.

- Reorganisation: further rainfall generates flow in the upper reach.

- Potential degraded state: reduced flow permanence.

The key components for lower gaining reach are (Fig. 4):

- Exploitation: river flow from the upper reach (if any) and seepage from groundwater (from river recharge and rainfall recharge).

- Accumulation: river flow in lower reach.

- Disturbance-release: groundwater and surface water abstraction leading to drying river bed.

- Reorganisation: further rainfall recharge or river flow.

- Potential degraded state: reduced flow permanence.

The adaptive cycles for the flow regimes of the upper and lower reaches are linked by both surface and groundwater. If there is sufficient rainfall in the upper catchment there can be a surface water flow from the upper to lower reaches. Even with a dry reach, there can be a contribution from groundwater to the lower reach from the river flow seepage to groundwater in the upper reaches. For the Selwyn River flow regime to be sustainable the reduced flow permanence from surface and groundwater abstraction should not reduce the flow permanence to adversely affect the fish ecology. 


\subsection{Adaptive cycle for fish ecology and the drying reach of the Selwyn River}

Intermittent streams are highly disturbed ecosystems. Stream drying is stressful for fish and can cause heavy and widespread mortality. Fish in streams that desiccate entirely over considerable lengths must seek refuge in perennial reaches at the onset of drying and recolonize intermittent reaches from those refugia upon rewetting [11]. The adaptive cycle for fish ecology and the drying reach of the Selwyn River can be defined as follows (Fig. 5):

- Exploitation: fish colonisation on rewetting of intermittent reach.

- Accumulation: increased fish density and diversity.

- Disturbance-release: drying of river bed leading to loss of fish.

- Reorganisation: fish recolonisation when river flow returns.

- Potential degraded state: decline in fish density and diversity with reduced flow permanence.

Studies have investigated the relationship between flow permanence and fish ecology [11]. The relationship between fish density and flow permanence is shown in Fig. 6. There appears

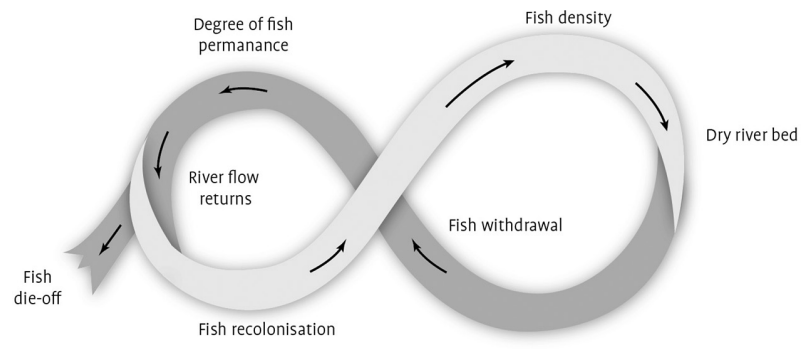

Figure 5: Adaptive cycle for fish ecology and the drying reach of the Selwyn River.

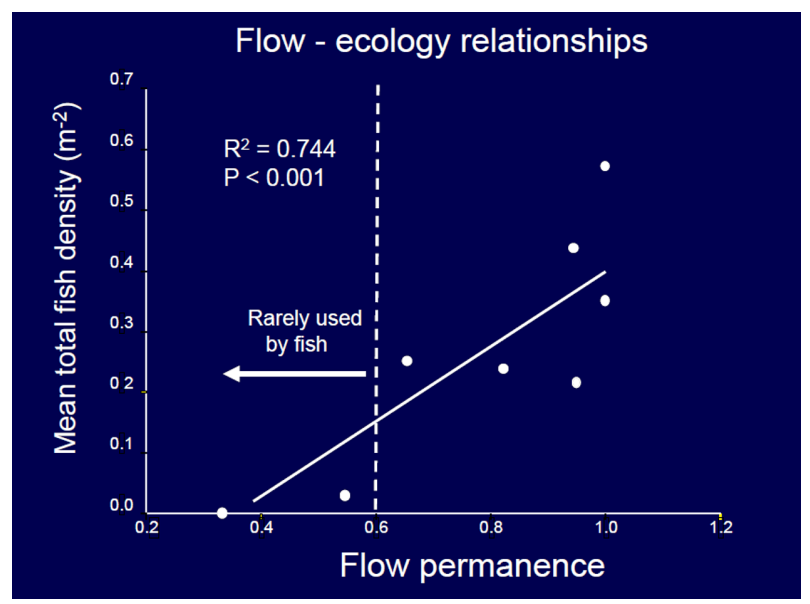

Figure 6: Relationship between fish density and flow permanence in the Selwyn River [10]. The graph plots mean total fish density against flow permanence. There is a critical threshold at 0.6 . The river is rarely used by fish when flow permanence is less than $60 \%$. 
to be a threshold when flow permanence is below 0.6 that few fish species remain and are unable to recolonise. As shown in Fig. 3, substantial lengths of the Selwyn River both in the losing and gaining sections have flow permanence below $60 \%$.

\subsection{Management interventions for the drying reach of the Selwyn River}

The sustainability analysis highlights the significance of maintaining flow permanence as the critical variable. The adaptive cycle processes also identify possible points of intervention to address the sustainability issue in relation to river flow. The adaptive cycles show that groundwater abstraction leading to lowering of the water table is a critical variable on the sustainability failure pathway.

One possible management intervention is the reduction in groundwater abstraction. Groundwater allocation limits have been set for the groundwater zones underlying the Selwyn catchment (i.e. Selwyn-Waimakariri zone and Rakaia-Selwyn zone). The groundwater allocation limits recommended by the regional council were based on maintaining flow in groundwater-fed streams such as the lower reaches of the Selwyn River [12]. However, applicants seeking groundwater allocations have successfully applied through the Resource Management Act consenting process. Decisions by independent hearing commissioners and through appeals to the Environment Court have led to allocations in excess of the recommended limits [13].

A second possible management intervention is the use surface water external to the Selwyn catchment for irrigation. This reduces the demand for groundwater withdrawal. Furthermore leakage to groundwater from irrigation increases recharge to the aquifers. The Central Plains irrigation scheme which draws water from the Rakaia and Waimakariri Rivers for irrigation in the Selwyn catchment is an example of this approach. The sustainability analysis of this approach with respect to water quality is considered in the next section.

A third possible management intervention is the use of surface water external to the Selwyn catchment for managed aquifer recharge. This intervention has been supported by the Selwyn Waihora Zone Committee in their addendum to the Selwyn Waihora Zone Implementation Programme [14].

\section{NITRATE MANAGEMENT IN THE SELWYN CATCHMENT}

\subsection{Adaptive cycle for nitrate in the Selwyn catchment}

Figure 7 shows the results of monitoring of nitrate levels along the length of the Selwyn River. The impact of the groundwater contribution to nitrate levels is evident in the significant increases occurring in the gaining reach.

Figure 8 displays the adaptive cycle of nitrate in the Selwyn catchment and its lowland reaches. It is shown as a nested system to reflect the accumulation of nitrate in groundwater from land use intensification in the catchment and dominant linkage to the lowland reach of the Selwyn River from groundwater. The phases in the nested adaptive cycle are as follows:

- Exploitation of the catchment: increase in land use intensification.

- Accumulation of nitrate in groundwater: nitrate leaching into groundwater.

- Disturbance/release: increased nitrate levels in groundwater (threat to drinking water quality). 


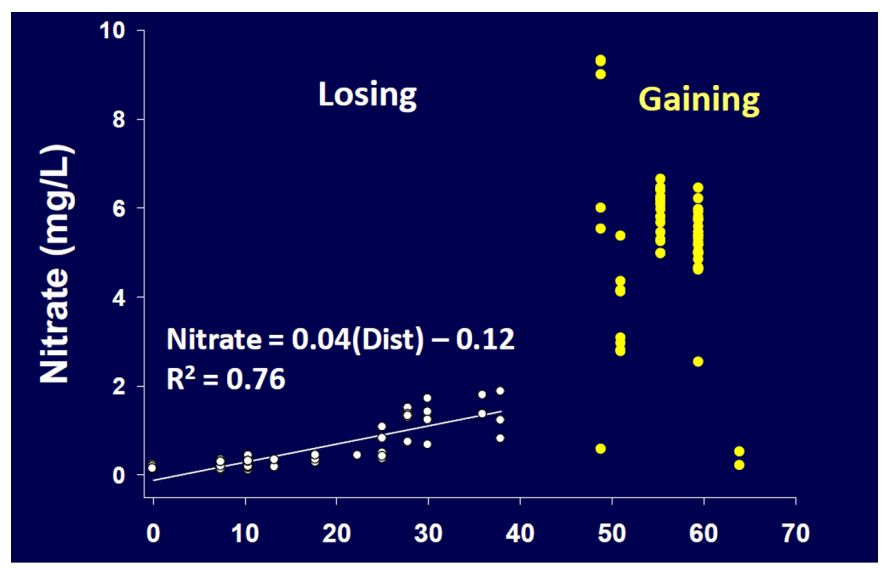

Figure 7: Nitrate levels along the length of the Selwyn River [10]. The graph plots nitrate concentration against distance downstream from the headwaters of the Selwyn River. In the run-off dominated losing reach there is a steady build-up of nitrate with distance downstream. However, in the gaining reach there is a significant increase in nitrate levels as nutrient-rich groundwater enters the river. Nitrate leaching from land use intensification has elevated nitrate levels in groundwater.

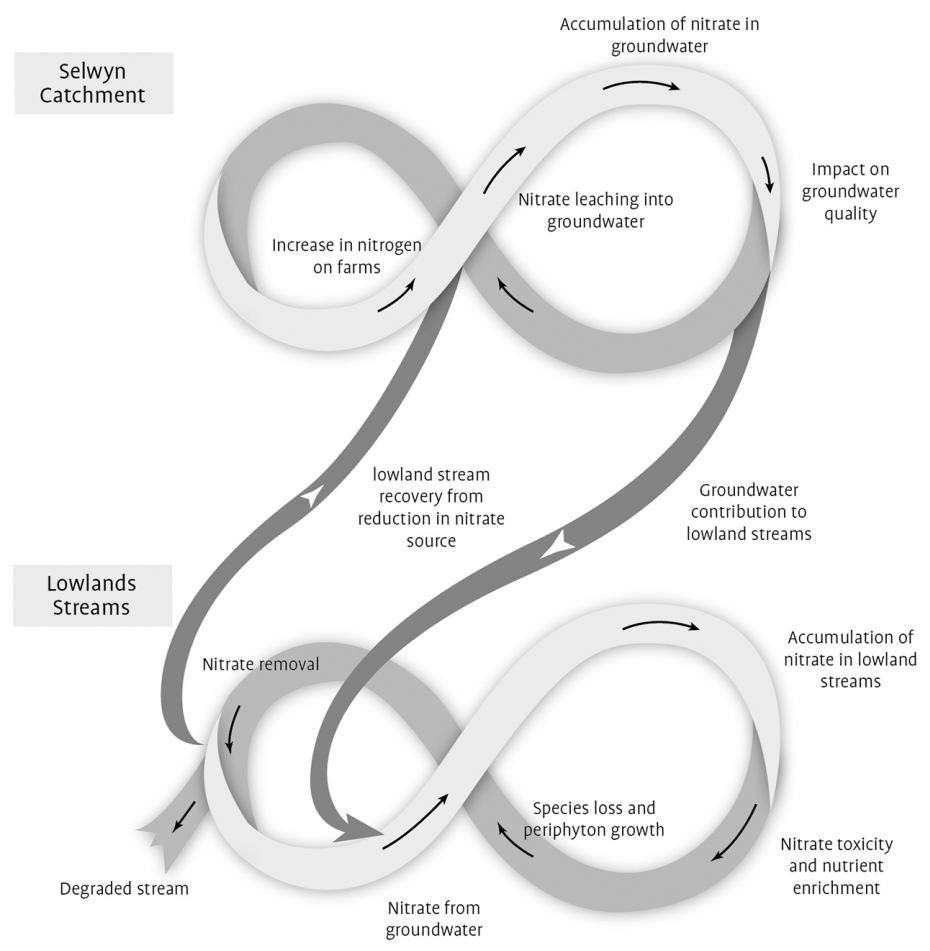

Figure 8: Adaptive cycle of nitrate effects in Selwyn catchment and lower reach of the Selwyn River. 
- Linkage between catchment and lowland streams: groundwater discharge to lowland streams.

- Accumulation in groundwater-fed lowland streams: increased flow and increased nitrate in gaining reach of Selwyn River.

- Disturbance/release in groundwater-fed lowland streams: increased nitrate toxicity leading to species loss and increased nutrient enrichment (link with phosphorus) leading to periphyton growth.

- Reorganisation in lowland streams: recovery in lowland streams is reliant on reduction in nitrate sources from land use intensification in the catchment.

- Reorganisation in the catchment: reduce nitrate leaching from land use.

- Potential degraded state: the degraded groundwater quality of drinking water supplies, nitrate toxicity in streams leading to species loss; and periphyton growth in stream degrading freshwater ecology.

There is a further link from the Selwyn River and other groundwater-fed streams that discharge into Lake Ellesmere/Te Waihora in relation to nutrient contamination of the lake. However, this is beyond the scope of this paper.

\subsection{Critical variables and thresholds for sustainable management}

The issues concerning nitrate contamination were significant considerations in the consenting process for the Central Plains irrigation scheme [15]. The Central Plains scheme is designed to irrigate approximately 60,000 ha of the Canterbury plains, much of it in the Selwyn catchment. The scheme is based on using water from both the Rakaia and the Waimakariri Rivers rather than groundwater abstraction.

While the irrigation rates and nitrate leaching rates are site specific, indicative figures are that the quantity of soil drainage for irrigated pasture is around $500 \mathrm{~mm} / \mathrm{yr}$ compared to dryland farming of around $200 \mathrm{~mm} / \mathrm{yr}$. Nitrate nitrogen leaching rates are of the order of $17 \mathrm{~kg} / \mathrm{ha} / \mathrm{yr}$ for dryland pasture and $42 \mathrm{~kg} / \mathrm{ha} / \mathrm{yr}$ for irrigated pasture. The Central Plains irrigation scheme would add approximately an additional $750,000 \mathrm{~kg} / \mathrm{yr}$ of nitrate nitrogen compared to about $2,550,000 \mathrm{~kg} / \mathrm{yr}$ from both dryland and irrigated areas in the Central Plains command area (i.e. adding about $30 \%$ to the nitrate-nitrogen load) [15].

Thresholds have been identified in relation to the critical water quality variables of nitrate in groundwater for drinking water supply, nitrate toxicity for freshwater ecology, and, filamentous algae and macrophyte cover in relation to nutrient enrichment. Groundwater is the dominant form of drinking water supply in the Selwyn catchment. The nitrate standard (maximum acceptable value) is $11.3 \mathrm{mg} / \mathrm{L}$. Already $3 \%$ of monitoring wells exceed this value. In relation to nitrate toxicity, nitrate concentrations in the lower reaches of the Selwyn River exceeded the threshold for chronic toxicity of highly disturbed systems in environments that are considered measurably degraded $(3.6 \mathrm{mg} / \mathrm{L}$ nitrate-nitrogen, median value). For algae in lowland streams the maximum limit for chlorophyll $a$ is $200 \mathrm{mg} / \mathrm{m}^{2}$ : this is exceeded $95 \%$ of the time in the Selwyn River. It was also noted that all trout fisheries are severely depleted in comparison with several decades ago [15].

The commissioners who were hearing the consent application acknowledged that without doubt irrigation of the Central Plains scheme will increase nitrogen concentrations in both underlying and down-gradient aquifers, and in lowland streams and Lake Ellesmere/Te Waihora recharged by these groundwaters. The commissioners noted there is a degree of conflict with relevant objectives and policies but considered the likely adverse effects will be 
minor. The consent was granted subject to the adoption of best management practices through Farm Environment Plans to mitigate the impacts of land use intensification [15].

This situation is clearly unsustainable with current nitrate levels. It is also predicted to get worse without further land use intensification because of the time lag in groundwater transport from the recent intensification to the groundwater system and lowland streams. Additional intensification even with mitigation measures will further degrade a compromised system.

\subsection{Management interventions for nitrate management in the Selwyn catchment}

The sustainability analysis indicates that nitrate levels lead to unsustainable outcomes in the Selwyn catchment. Because of the link between land use intensification at the catchment scale and nitrate loads in groundwater and lowland streams, identification of management interventions in relation to land use are appropriate. However, in terms of achieving sustainability it is not sufficient for new developments like the Central Plains scheme to adopt best management practices. There also needs to be reductions in nitrate from existing land use either through improved management practices or changes to less nitrogen intensive land uses.

In relation to groundwater supply there is an option of using deeper wells. Nitrate contamination currently affects about the upper 50-100 $\mathrm{m}$ of the aquifer system [16]. Drawing water from greater depths (and at greater cost) is a possible management intervention.

The sustainability analysis also highlights the problem with effects-based legislation like New Zealand's Resource Management Act. With the emphasis on assessing whether the effects of new projects are less than minor, the legislation fails to adequately address the cumulative effects of new and existing development, particularly with respect to diffuse sources of contaminants from land use intensification. Note that unlike the EU Water Framework Directive with a focus on river basin management [17], New Zealand's Resource Management Act has a focus on "avoiding, remedying or mitigating the adverse effects of activities on the environment" [18]. An important management intervention is the adoption of legislative frameworks that address resource and environmental sustainability.

\section{DISCUSSION AND CONCLUSIONS}

The nested adaptive systems approach provides a framework for the definition of sustainability limits. The approach considers adaptive cycles (i.e. exploitation/accumulation/ disturbance-release/reorganisation) at multiple spatial scales. The approach identifies critical variables that can cause the adaptive cycle to fail and identifies the linkages between different spatial scales that need to be maintained. The critical variables and the linkages that determine the limits will depend on the socio-ecological system under consideration. A systems approach with multiple spatial scales can identify appropriate management interventions that are not adequately addressed by effects-based management.

This paper has highlighted the sustainability analysis for two significant issues for the Selwyn River catchment - water abstraction and land use intensification effects on water quality - where management interventions have been insufficient to achieve sustainable outcomes. Nested adaptive system approaches have also been applied to other aspects of the catchment such as the management of Te Waihora/Lake Ellesmere. Resilience analysis led to a restoration programme for the most vulnerable components of the lake ecosystem, 
e.g. adjusting the timing of lake openings to facilitate the migration of longfin eels [19], where previous multi-objective catchment management approaches resulted in no action.

In relation to water quantity, groundwater abstraction in the Selwyn catchment has led to an increase in frequency and length of the dry river bed in the Selwyn River. For the critical variable of flow permanence, the threshold for maintaining fish populations is $60 \%$. For substantial lengths of both the losing and gaining reaches of the Selwyn River flow permanence does not achieve this threshold. Potential management interventions include reducing groundwater abstraction or, using water external to the catchment for irrigation or managed aquifer recharge.

Sustainability analysis of using water from rivers external to the Selwyn catchment for irrigation was also considered. The analysis showed that existing land use development had already exceeded the thresholds for groundwater drinking water quality with respect to nitrates, for nitrate toxicity in lowland streams, and, for algae in lowland streams. Further land use intensification, even with mitigation will exacerbate an already unsustainable situation for the Selwyn catchment.

To achieve sustainability for water quantity, this leaves reduction in groundwater abstraction or managed aquifer recharge from external sources as possible management interventions. For water quality, sustainability in relation to nitrate contamination requires catchment-wide improvements in land use practices to reduce nitrate leaching and/or a shift to less nitrogen intensive land use.

Furthermore, the reliance on effects-based legislation that focusses on mitigating the adverse effects of new development is not achieving sustainable outcomes. Allowing incremental increases in further groundwater abstraction and land use intensification is leading to cumulative effects that exceed sustainability thresholds for resource availability and water quality impairment. A legislative framework that incorporates resource and environmental sustainability is needed to manage the cumulative effects of new and existing development in the catchment.

\section{REFERENCES}

[1] Gunderson, L.H. \& Holling, C.S., Panarchy: Understanding Transformations in Human and Natural Systems, Island Press: Washington, 2002.

[2] Walker, B. \& Salt, D., Resilience Thinking: Sustaining Ecosystems and People in a Changing World, Island Press: Washington, 2006.

[3] Holling, C.S. \& Gunderson, L.H., Resilience and adaptive cycles (Chapter 2). Panarchy: Understanding Transformations in Human and Natural Systems, eds L.H. Gunderson \& C.S. Holling, Island Press: Washington, pp. 25-62, 2002.

[4] Schumpeter, J., Capitalism, Socialism and Democracy, Routledge: London, 1942.

[5] Carpenter, S.R., Brock, W. \& Hanson, P., Ecological and social dynamics in simple models of ecosystem management. Conservation Ecology, 3(2), 1999.

[6] Jenkins, B.R., Sustainable water management analysis using nested adaptive systems. WIT Transactions on Ecology and Environment, 196, pp. 39-52, 2015. https:/doi.org/10.2495/WRM150041

[7] Taylor, K.J.W. (ed), The Natural Resources of Lake Ellesmere (Te Waihora) and its Catchment, Canterbury Regional Council: Christchurch, 1996.

[8] Jenkins, B.R., From mitigation to sustainability: the evolution of incorporating environmental factors into development decisions in Australasia. International Journal of Sustainable Development and Planning, 11(6), pp. 920-929, 2016. https:/doi.org/10.2495/SDP-V11-N6-920-929 
[9] Larnad, S.T., Hicks, D.M., Schmidt, J., Davey, A.J.H., Dey, K., Scarsbrook, M., Arnscott, D.B. \& Woods, R.A., The Selwyn River of New Zealand: a benchmark system for alluvial plain rivers. River Research and Applications, 24(1), pp. 1-21, 2007, available at: www.interscience.wiley.com.

https:/doi.org/10.1002/rra.1054

[10] Larnad, S.T., The Selwyn River/Waikirikiri. Living Lakes Symposium, Lincoln University, Nov 7-8, 2013.

[11] Davey, A.J.H. \& Kelly, D.J., Fish community responses to drying disturbances in an intermittent stream: a landscape perspective. Freshwater Biology, 52, pp. 1719-1733, 2007.

https:/doi.org/10.1111/j.1365-2427.2007.01800.x

[12] Environment Canterbury, Groundwater Allocation Limits: land-based recharge estimates. Report U04/97, Environment Canterbury: Christchurch, 2004.

[13] Environment Canterbury, ecan.govt.nz/services/online-services/monitoring/groundwater-allocation/zone-summary-reports/Pages/rakaia-selwyn.aspx.

[14] Canterbury Water, Selwyn Waihora ZIP Addendum, Environment Canterbury: Christchurch 2013.

[15] Joint Decision and Recommendation of Independent Commissioners 28 May 2010 in the matters of various applications by Central Plains Water Trust, 2010, available at: http://ecan.govt.nz/publications/Pages/cpw-decision.aspx.

[16] Bidwell, V. \& Norton, N., Section 41C Report: Review of Nutrient and other Contamination Issues in the matter of various applications by Central Plains Water Trust to the Canterbury Regional Council, 2009, available at: http://ecan.govt.nz/get-involved/ consent-projects/past-notifications/central-plains-water/Pages/section-41c-report.aspx.

[17] European Commission (2016) Introduction to the new EU Water Framework Directive, available at: http://ec.europa.eu/environment/water/water-framework/info/intro_ en.htm. Accessed 24 April 2016.

[18] New Zealand Government, Section 5: Purpose, Resource Management Act, NZ Government: Wellington, 1989.

[19] Te Waihora Co-Governance Group, Whakaora Te Waihora: Joint Cultural and Ecological Restoration Plan, Environment Canterbury: Christchurch, 2011, available at: http://ecan.govt.nz/publications/General/joint-cultural-ecological-restoration-plan-0912-2011.pdf. 